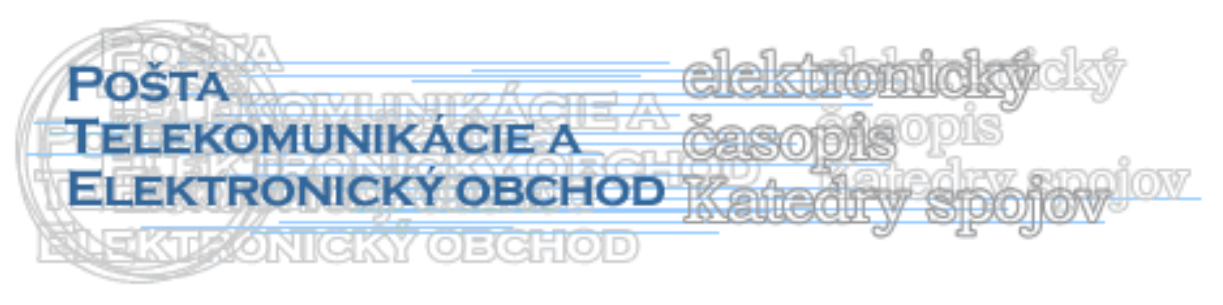

\title{
VÝZNAM A PERSPEKTÍVA LISTOVÝCH ZÁSIELOK
}

\author{
Lucia Madleňáková*
}

\section{Úvod}

Z historického vývoja je zrejmé, ž listové zásielky boli už v minulosti dôležitou a neodmyslitel'nou súčast'ou l'udskej spoločnosti. S vývojom a vyspelost'ou spoločenského zriadenia nadobúdalo stále významnejšie a pevnejšie miesto potreba prepravy správ a používanie listových zásielok sa stalo nevyhnutnost'ou.

Jednou zo základných činností pošty je aj dnes premiestňovacia činnost'. V rámci tejto činnosti ponúka SP, a.s. viacero služieb súvisiacich s listovými zásielkami, ktoré tvoria najväčšiu čast' objemu výkonov. No v súčasnosti sú k dispozícií aj nové rýchlo sa rozvíjajúce alternatívne možnosti prenosu správ. A po liberalizácií poštového trhu je možné predpokladat' práve úbytok objemu výkonov v tomto segmente. Dôvodom môže byt' najmä rastúci trend strategických spojenectiev nadnárodných spoločností poskytujúcich poštové služby a tiež rýchly vývoj expresných a kuriérskych služieb založených na podpore moderných informačných technológií.

Práve zrovnoprávnenie postavenia národného operátora na trhu poštových služieb s ostatými operátormi otvára potrebu prehodnotit' okrem ekonomických a tarifných podmienok poskytovania poštových služieb aj samotné portfólio týchto produktov s ciel’om udržat' si dominantné postavenie na trhu.

\section{Hodnotenie listových zásielok z hl'adiska a ich postavenia na trhu a konkurencie}

V súčasnosti je $\mathrm{v}$ registri poštových podnikov na Poštovom regulačnom úrade zaregistrovaných 13 spoločností vrátane Slovenskej pošty, a.s. ide o podniky, ktoré podliehajú registrácie v zmysle ustanovenia $§ 15$ zákona č. 507/2001 Z. z. o poštových službách v znení neskorších predpisov a podl'a podmienok určených vo všeobecnom povolení na poskytovanie poštových služieb.

Slovenská pošta, a.s. svoje základné aktivity zameriava na listové zásielky, poštové balíky a peňažné služby. Z pohl'adu tvorby výkonov predstavuje jej hospodárenie $68,1 \%$ podiel na trhu.

V oblasti listov má pošta $\mathrm{v}$ súčasnosti dominantné postavenie a jej podiel na trhu prestavuje 96,2\%. Konkurencia má podiel na trhu 3,8\%, z ktorých len spoločnost' UPS prestavuje $1,7 \%$ a DHL $1,5 \%$ trhový podiel. Ostaní operátori sa podiel'ajú spoločne približne $0,6 \%$.

\footnotetext{
* Ing. Lucia Madleňáková, PhD., Katedra spojov, Fakulta PEDaS, Žilinská univerzita v Žiline, Univerzitná 1, 010 26, Žilina

tel.: +421/41/513 3125, fax: $+421 / 41 / 5655615$

e-mail: Lucia.Madlenakova@fpedas.utc.sk
} 
Rapídny pokles objemu listových zásielok na území SR nepredpokladá SP, a.s. ani po úplnej liberalizácie poštového trhu, pretože:

- záujem o listové produkty aj napriek nárastu konkurencie ale najmä substitučných produktov spôsobených nárastom elektronizacie neklesá, skôr naopak, SP, a.s. očakáva medziročný nárast o $3 \%$,

- distribúcia listov s pridanou hodnotou (doporučene, do vlastných rúk, ...), nie je pre konkurentov až tak zaujímavým segmentom vzhl'adom na zložitost' a nákladovost'.

Vo všeobecnosti však možno očakávat' po liberalizácií čiastočný pokles podielu SP, a.s. na poštovom trhu. V oblasti listových zásielok.

\section{Hodnotenie listových zásielok z hl’adiska štruktúry zákazníkov}

Odberatel'mi služieb SP, a.s. na vnútornom trhu je široké spektrum zákazníkov, ktoré sa skladá z orgánov štátnej správy, regionálnych inštitúcií, podnikatel'ských subjektov a občanov. Najväčší podiel na celkovom objeme výnosov tvoria práve orgány štátne správy, regionálne inštitúcie a podnikatel'ské subjekty, čo prestavuje $85 \%$ z celkových výnosov. Obyvatel'stvo sa na celkovom objeme výnosov podiel'a len $15 \%$.

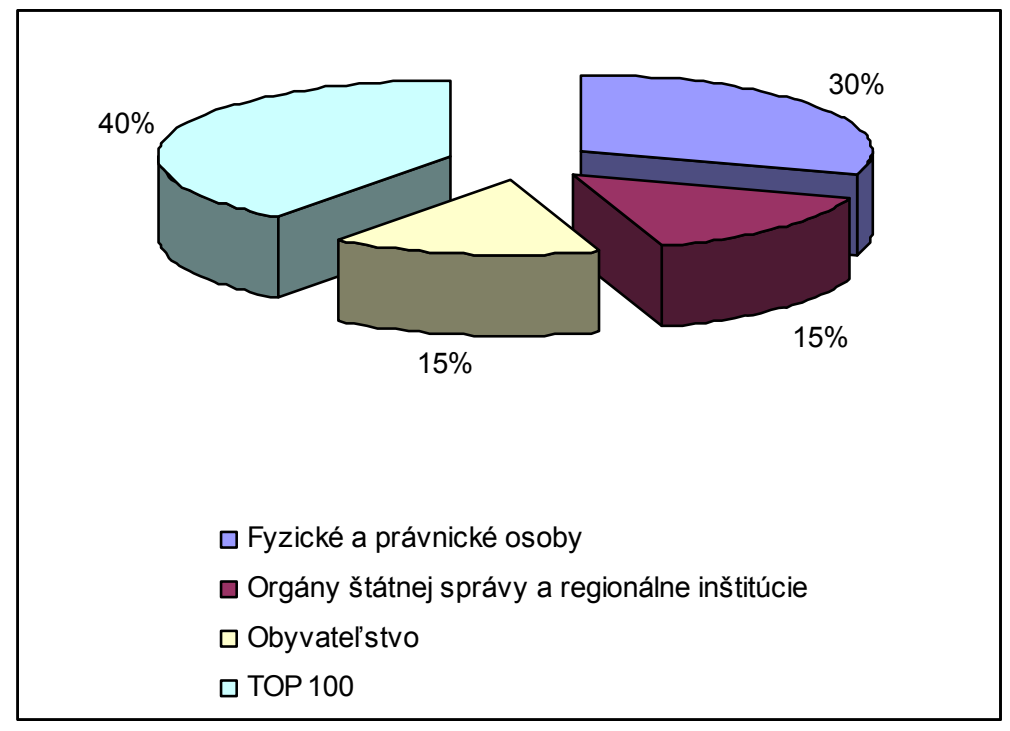

Obrázok 1 Štruktúra zákazníkov SP, a.s.

Na základe štatistických prieskumov SP, a.s. z roku 2005 dosahuje hustota telefonizácie v pevných linkách $\mathrm{v}$ domácnostiach $50 \%$ a penetrácia mobilných operátorov $80 \%$, objem užívatel'ov, ktorí majú prístup k internetu sa neustále zvyšuje. V súčasnosti sa odhaduje na 2 mil. osôb. Z týchto dôvodov substitučné služby, ponúkané novými technológiami ohrozujú poštové služby týkajúce sa prenosu informácií, bankových i poist'ovacích služieb, oblasti reklamných zásielok, elektronického nákupu a podávania štatistických, daňových a odvodových formulárov.

\section{Predpoklad vývoja poštových služieb}

Výrazný rozvoj poštového trhu sa naštartoval a jeho zmeny možno zretel'ne badat' najmä od poslednej štvrtiny 20. storočia. Za hlavné hnacie sily tohto stavu možno považovat' najmä technologický rozvoj, či ekonomické, politické regulačné a inštitucionálne faktory, ale tiež zmenu správania sa zákazníkov a rastúce požiadavky podnikatel’ov. 


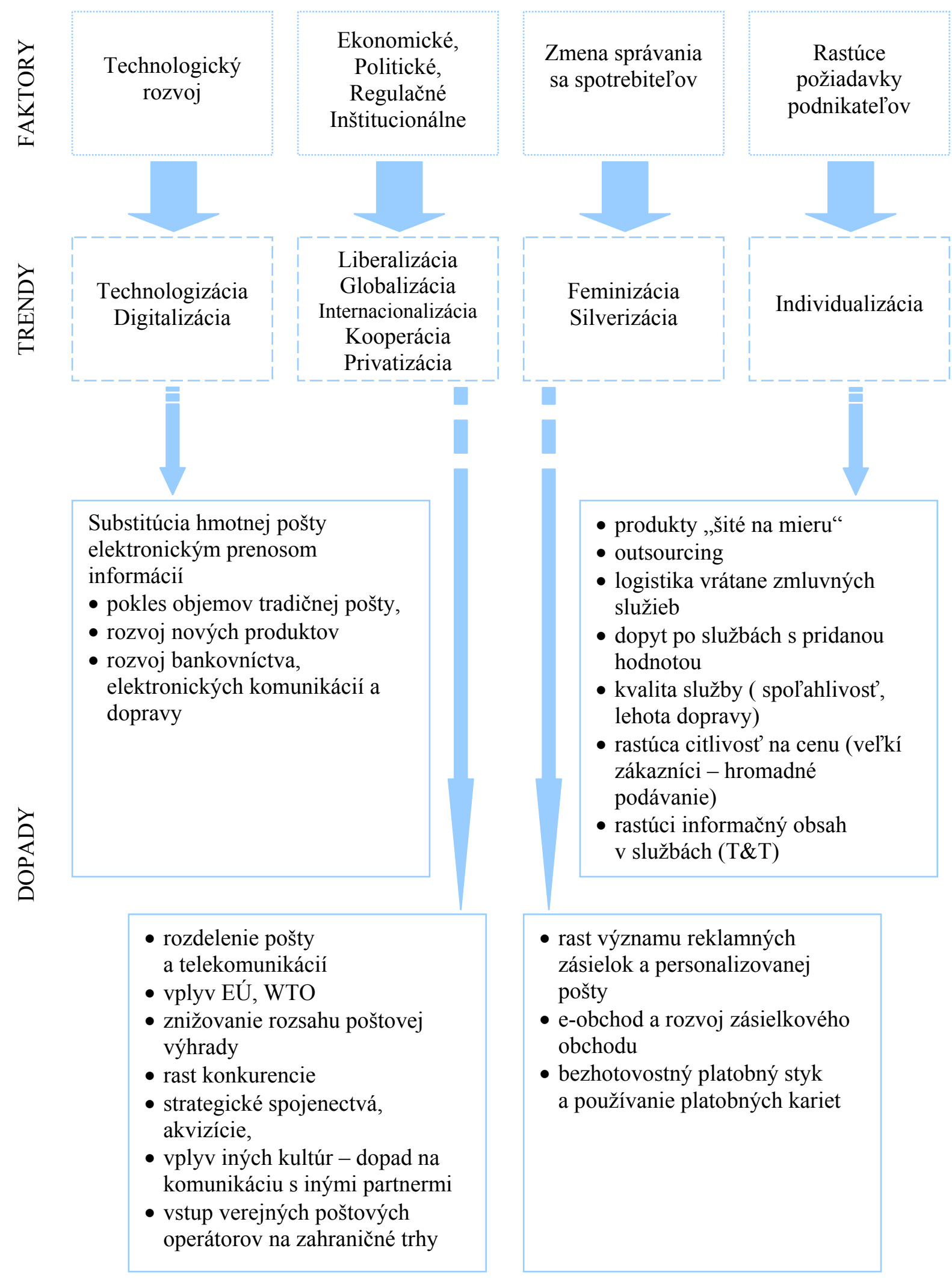

Obrázok 2 Faktory a trendy ovplyvňujúce vývoj poštových služieb

Technologický rozvoj umožňuje neustála a intenzívna konvergencia telekomunikácií, informačných technológií a spotrebitel'skej elektroniky. Nahradzovanie hmotnej pošty elektronickým prenosom informácií je pre poštu hrozbou a výzvou zároveň, najmä ak 
elektronické produkty sú často lacnejšie a rýchlejšie než hmotné listové zásielky, produkty či služby.

Ekonomické, politické a regulačné zmeny neustále ovplyvňujú ponuku a hospodársku sút’až a často viedli a aj vedú $\mathrm{k}$ novým inštitucionálnym zmenám. Ako jasný príklad možno uviest' EÚ, WTO a pod. Liberalizácia poštového trhu sa už stala súčast'ou opatrení nových vlád, pretože čoraz viac sa ujíma myšlienka, že trhy s hospodárskou sút'ažou sú optimálne na poskytovanie efektívnych služieb. Čo je však nejasné, to je krok, kedy možno reformu pošty realizovat'. Vlády - obávajúc sa sociálnych a politických t’ažkostí, nepostupujú rýchlo a jednorazovým rozhodnutím, ale postupným znižovaním ochranárskych bariér, čo sa prejavuje tým, že reforma je postupná a pomáha národným poštovým operátorom zvyšovat' ich výkonnost' a pripravit' sa na trh s úplnou hospodárskou sút’ažou, v rámci harmonizácie EÚ.

Štúdie a prieskumy potvrdzujú, že aj spotrebitel' sa stáva vzdelanejším a náročnejším. Priaznivo reaguje na nové technológie a začína si vyberat' medzi alternatívami, ktoré sú ponúkané, pričom využitie internetu už nie je zriedkavost'ou aj v domácnostiach. Stáva sa tak vd’ačným ciel'om poist'ovacích, bankových služieb, katalógového obchodu, elektronického nákupu, reklamných zásielok a pod. tento nový druh spotrebitel'a mení celý nákupný cyklus: od reklamy a marketingu až po miesto a čas, kedy sa nákup uskutočňuje.

Podnikatelia odberatelia poštových služieb požadujú zlepšenú úroveň služieb pri nižších cenách, pretože majú k dispozícií väčší výber komunikačných prostriedkov, ako aj služby a produkty šité na mieru. Hmotná pošta zostáva nad’alej dôležitým komunikačným médiom, ale jej podiel na tomto rastúcom trhu klesá. Rast zaznamenáva len v poštových službách s nízkou cenou a nízkou pridanou hodnotou.

Bezpečnost', tento faktor nadobudol význam najmä poslednom období v súvislosti s rastúcimi prejavmi terorizmu, a najmä po roku 2001, pri zistení, že doprava poštou patrí medzi najrizikovejšie distribučné kanály. Jej dôsledkom je radikálny nárast prísnych bezpečnostných opatrení a kontrol, predovšetkým na strane leteckých spoločností, ale aj samotných poštových operátorov.

Vzájomným pôsobením jednotlivých faktorov sa vyvinulo niekol'ko zásadných trendov, t.j. základných smerov vývoja poštových služieb:

- technologizácia je výsledkom prudkého rozvoja a zavádzania nových informačných technológií, pričom priniesla dynamický rast komunikačných médií, integráciu do zásobovacích ret’azcov zákazníka a mnohokanálovú distribúciu, doplňujúcu a súčasne konkurujúcu tradičným siet’am pôšt.

- digitalizácia spôsobuje substitúciu hmotnej pošty (elektronická pošta, platobné transakcie a prenosy dokumentov typu ,on-line“),

- liberalizácia (prípadne deregulácia) znamená odstránenie prekážok pre hospodársku sút'až a rozvoj konkurencie, a to predovšetkým na trhoch, ktoré preukazujú monopolistické črty, vrátane trhu poštového. V súvislosti s poštou ide o znižovanie rozsahu prípadne zrušenie zákonne vyhradených služieb.

- globalizácia sa spravidla spája s rozširovaním nadnárodných podnikov na trhy mimo vlastného štátu. Silný domáci podnikatelia rozširujú svoje aktivity - globalizujú sa, aby na jednej strane znížili svoje náklady a na druhej strane zväčšili svoj podiel na trhu a aj svoje zisky.

- trh sa postupne internacionalizuje, t.j. stáva sa otvoreným. Je pritom nevyhnutné poznat' špecifiká národných kultúr a národných trhov preto je potrebná vzájomná spolupráca národných poštových operátorov, ktorá je ich zásadnou a tradičnou prevádzkovou činnost'ou.

- privatizácia - poštový sektor je i nad’alej prevažne štátnym vlastníctvom, vlna privatizácie v oblasti telekomunikačných podnikov je však príkladom, ktorý vedie 
vlády vyspelých krajín $\mathrm{k}$ tomu, aby uvažovali o súkromnom vlastníctve aj v oblasti pošty. Za prvotné ciele privatizácie pritom možno považovat':

o infúziou súkromného kapitálu maximalizovat' komerčné tlaky a disciplínu,

o zvýšit' konkurencie schopnost',

o dat' pošte príležitost' na sút’aženie s jej konkurentmi za rovnakých podmienok.

- feminizácia je súčasným trendom v podnikatel’skej oblasti, rastúci podiel žien v zamestnaní, ale najmä podnikatel'skej sfére a na manažérskych postoch dnes už nie je výnimkou, čo však prináša rast najmä v oblasti osobnej komunikácie.

- silverizácia - l'udstvo starne, a jeho mobilita je úplne iná ako kedykol’vek predtým, z čoho vyplývajú zmenené nároky na komunikáciu.

- individualizácia - rýchli rast produktov šitých na mieru, z dôvodu vzniku rôznych diferencovaných skupín zákazníkov.

Tieto trendy sa podla regionálnych a národných podmienok modifikujú a špecifikujú a nadväzne sa prejavujú širokým spektrom dopadov na poštové služby a na ich národné a medzinárodné trhy. V tejto súvislosti je potrebné konštatovat', že $v$ súčasnosti poštový trh v pravom zmysle neexistuje. Pôvodné poštové služby a úlohy pôšt sú tento krát rozdelené medzi štyri špecializované trhy:

- komunikačný trh (dátová komunikácia, internet, telefón,...),

- logistika (kuriérske a expresné služby, balíková pošta, ...),

- finančné služby (bankové, poist'ovacie, poštové peňažné služby, ...),

- reklamné služby (reklamné adresované zásielky, propagačné zásielky, letáky, ...)

\section{Komunikačný trh}

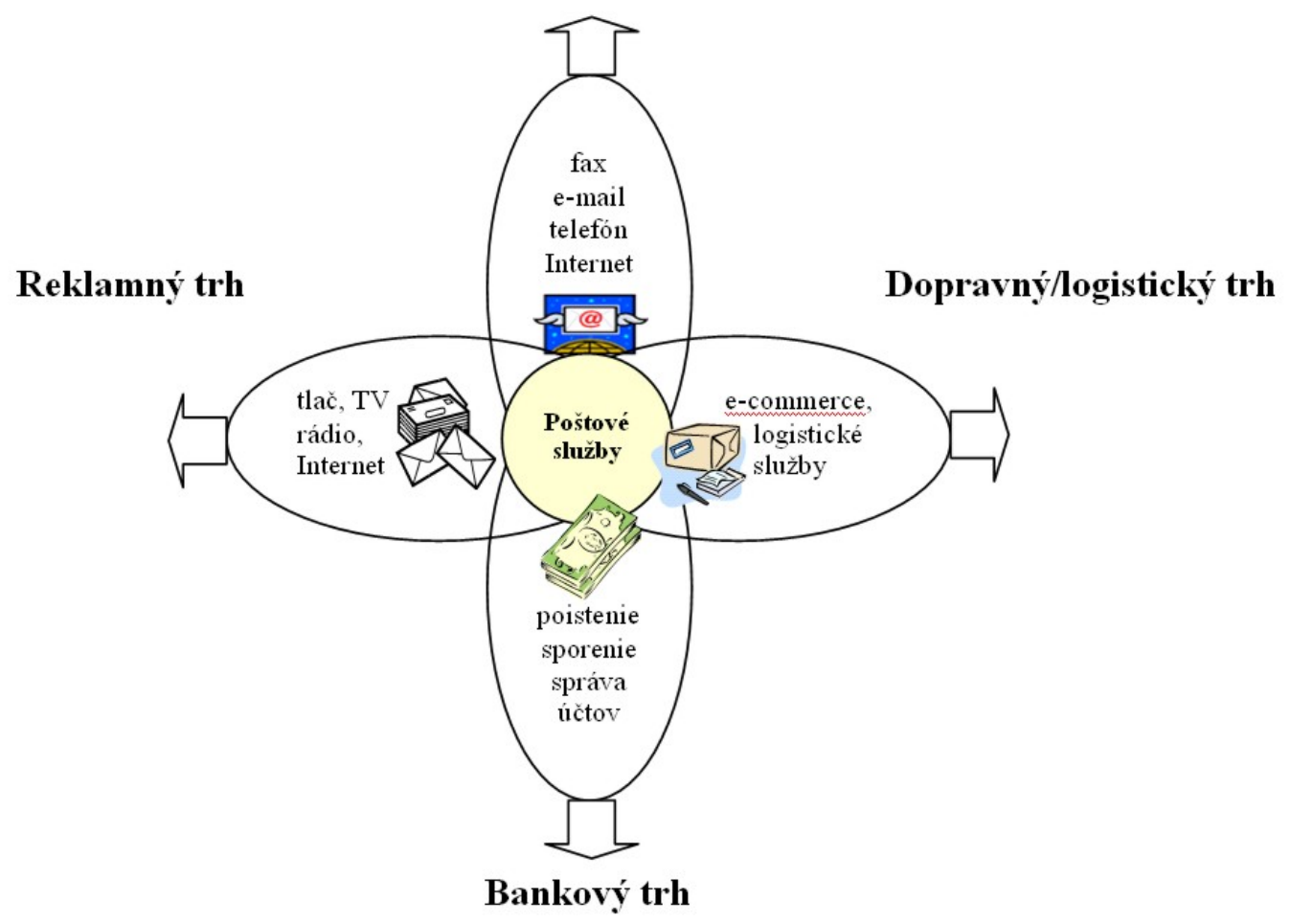

Obrázok 3 Sektor poštových služieb

Nové trendy v oblasti vývoja listových zásielok SP, a.s.

Mobilná komunikácia a internet hlboko zasahujú aj do života najväčšieho slovenského poštového operátora. E-maily a SMS správy v mnohých prípadoch výrazne zredukovali alebo úplne nahradili tradičné poštové produkty ako listy, pohl'adnice či telegramy. Internet však nie 
je len hrozba, ale stáva sa i príležitost'ou a výzvou pre uvádzanie nových produktov, ktoré budú pre zákazníka zaujímavé a najmä lákavé z pohl'adu ul'ahčenia prístupu k službe a pri priamom kontakte s poštou. V rámci týchto trendov sa očakáva na $\mathrm{SP}$, a.s. v budúcom roku spustenie nových produktov - elektronických služieb.

\begin{tabular}{|l|l|}
\hline \multicolumn{3}{|c|}{ Nové elektronické služby SP, a.s. } \\
\hline Hybrid mail & $\begin{array}{l}\text { zasielanie korešpondencie v elektronickej forme cez webový portál } \\
\text { pošty, ktorá zabezpeči jej tlač, zaobálkovanie a zaslanie } \\
\text { adresátovi/adresátom. Platba bude prebiehat' prostredníctvom } \\
\text { platobného portálu, prípadne príkazu na úhradu. }\end{array}$ \\
\hline Služba eXpert & $\begin{array}{l}\text { on-line rozšírenie už existujúcich služieb expresného doručovania. } \\
\text { Umožní objednávanie zásielok cez internet, prípadne dial'kové } \\
\text { sledovanie ich pohybu. }\end{array}$ \\
\hline Zásielkový obchod & $\begin{array}{l}\text { otvorenie virtuálnej predajne s tradičným poštovým tovarom } \\
\text { a zároveň aj ponukou skladovacích priestorov pre iných on-line } \\
\text { obchodníkov. Zákazník si bude môct' objednat' tovar z viacerých } \\
\text { predajní, pošta mu ho zašle v jednom balíku, čím sa znížia náklady na } \\
\text { balné a poštovné. }\end{array}$ \\
\hline
\end{tabular}

Záver

Slovenská pošta, a.s. ako doterajší poskytovatel' univerzálnej služby má z hl'adiska infraštruktúry a doručovania vybudované najlepšie postavenie na domácom poštovom trhu. $\mathrm{Aj}$ napriek tomu by však ale venovat' zvýšené úsilie do zavádzania nových trendov v oblasti listových zásielok. Ked’že tieto zásielky tvoria takmer $90 \%$ objem celkových príjmov, je potrebné vyvíjat' neustálu snahu v rozvoji doručovania v zmysle zachovania súčasného stavu aj po liberalizácií poštového trhu. Budúcnost' tohto segmentu je najmä v rozvoji elektronických služieb a budovaní nových spracovatel'ských centier za účelom efektívneho pokrytia celého územia.

\section{Literatúra}

[1] BORKOWSKI, S., ČOREJOVÁ, T. Instrumenty rozwiazywania problemów w zarzadzaniu. Wydawnictwo Wyzszeh Szkoly Zarzadzania i Marketingu w Sosnowcu, 2004, 107 s. ISBN 83-89275-46-5

[2] ČOREJOVÁ, T., MADLEŇÁKOVÁ, L.: K niektorým otázkam vývoja na poštových trhoch. In: Zborník z medzinárodnej vedeckej konferencie „Podniky v podmínkach procesu globalizace a integrace“: VŠB-TU Ostrava, 2003, ISBN 80-248-0498-0

[3] MADLENÁK, R.: The role of the postal enterprises at the electronic marketplace In: Telekomunikacja i poczta jako stymulatory rozwoju e-gospodarki w Polsce : Szczecin - Darłowo, maj 2005. - Szczecin: Wydział Zarządzania i Ekonomiki Usług, Uniwersytet Szczeciński, 2005. - ISBN 83-7241-477-7. - P. 169-174.

[4] MADLEŇÁKOVÁ, L.: Poštový trh v SR. In: Zborník príspevkov IV. ročníka odborného seminára PERNER'S CONTACT 2003 Pardubice : Univerzita Pardubice, 2003, s. 12-17, ISBN 80-7194-524-2

[5] Výročné správy, Slovenská pošta, a.s. , rok 2003, 2004

\section{Grantová podpora}

Príspevok vznikol na základe riešenia výskumného projektu VEGA 1/1265/04 Výskum siet’ových procesov v rámci odvetvových zoskupení firiem v SR, podporeného MŠ SR. 